\title{
Ender Grønlands økonomi og erhvervsudvikling i fisk?
}

Nauja Bianco, ekstern lektor ved Ilisimatusarfik, Grønlands Universitet ${ }^{1}$

Denne artikel undersøger de centrale spørgsmål, der knytter sig til økonomien og erhvervsstrukturen i Grønland og reflekterer over, hvad udviklingen på disse områder fortoeller os om det grønlandske samfund $i$ dag og dets muligheder i en fremtid, der kan byde på løsrivelse fra Rigsfoellesskabet. Artiklen viser, at - udover bloktilskuddet fra Danmark og aftalte indtogter fra EU, som udgør ca. 60\% af Selvstyrets indtogter - har grundlaget for Grønlands økonomi og erhvervsstruktur siden 1950'erne og 60'erne varet fiskeriet, der stadig blomstrer. Artiklen viser dog også, at Grønlands økonomi er enkeltstrenget og dermed følsom overfor udsving og ikke alene kan imødekomme indkomstbehovet for et selvstcendigt Grønland. Artiklen påpeger, at selvstcendighed vil krceve, at den grønlandske økonomi diversificeres, og at erhvervsstrukturen udvikles. Scerligt kunne den marine industri indenfor bioøkonomi udgøre et potentiale for innovation og produktudvikling. Der er også plads til ivcerkscetteri inden for den kulturelle og kreative industri. Turismeindustrien skal fortsat udvikles, og en omfattende strategi for at tiltrcekke udenlandske og direkte investeringer til Grønland bør udvikles.

Indledning

Umiddelbart efter indførelsen af selvstyre den 21. juni 2009 og med overførslen af kompetence for råstoffer til Grønland med råstoflovgivningen af 1. januar 2010, kunne man få indtryk af, at et "bonanza"-eventyr lå lige rundt om hjørnet, og at indtægter fra råstoffer ville kunne frigøre Grønland fra det danske bloktilskud indenfor en overskuelig årrække. Dette har ikke været tilfældet. Grønland har ikke i det første årti fået forløst råstofpotentialet, bloktilskuddet fra den danske stat udgør fortsat mere end halvdelen af Selvstyrets samlede indtægter og Grønlands dominerende økonomi og eksport er stadig fiskeriet.

Grønlands overordnede udfordring i lyset af ønsket om selvstændighed er at skulle erstatte de nuværende indtægter fra Danmark og EU, som udgør en betydelig del af Selvstyrets nuværende indtægter, med egne indtægter. Det kræver en udbygning af den private

\footnotetext{
${ }^{1}$ Nauja Bianco er indehaver af Isuma Consulting og ekstern lektor ved Ilisimatusarfik, Grønlands Universitet. Hun har tidligere været ansat i Udenrigsministeriet og som strategisk rådgiver i internationale forhold i Nordisk Råd og Ministerråd.
} 
erhvervssektor, og spørgsmålet er, hvordan dette kan blive muligt. Det er i den forbindelse interessant at se på, hvorvidt hjemmestyret og selvstyret har skabt et bedre fundament for en stærkere økonomi og erhvervsstruktur, end da Grønland helt og fuldt var en del af Danmark.

\section{Det særlige ved Grønlands økonomi}

Det særlige træk ved den grønlandske økonomi er, at den vigtigste indtægtskilde er bloktilskuddet, som udgjorde 3,6 mia. kr. i 2018, hvilket svarer til ca. 55\% af Selvstyrets indtægter (ekskl. værdien af bl.a. at opretholde et retsvæsen og et forsvar).

(Christensen 2018 I og II). Hertil kommer indtægter fra aftaler med EU, som bringer indtægterne op på de knap 60\%. Dermed skal andre indtægter hæves væsentligt for at realisere ønsket om uafhængighed af bloktilskuddet. Indtægtsbehovet for et selvstændigt Grønland kræver som minimum et bredere erhvervsgrundlag end det nuværende samt en højere effektivitet $\mathrm{i}$ både den offentlige og den private sektor. En tommelfingerregel for at skabe en fornuftig balance mellem indtægter og udgifter er, at den offentlige sektor ikke må være større end den private. Den grønlandske offentlige sektors andel af økonomien er meget stor, og det offentlige forbrug udgjorde 43\% af BNP i $2016 \bmod 25 \%$ i Danmark (Christensen 2018 I og II).

Bloktilskuddet påvirkes ikke af den økonomiske udvikling i Grønland, men reguleres årligt med stigningen i det generelle pris- og lønindeks i Danmark og af den danske finanslov. Det er både godt og skidt. Fordelen ved bloktilskuddet er, at pengene tilfalder landskassen, uanset om den grønlandske (egen)økonomi er god eller dårlig. Det grønlandske budget kan med andre ord regne med et fast og forudsigeligt beløb på trods af markedet. Ulempen kan være, at den grønlandske økonomi ikke mærker fluktuationerne i den globale markedsøkonomi, og bloktilskuddet kan således komme til at fungere som en sovepude, hvor man forsømmer at udvikle rammevilkårene for erhvervslivet og for effektiviteten i den offentlige sektor.

Efter bloktilskuddet er fiskeriet den største indtægtskilde. Det har de seneste år været indbringende på grund af høje verdensmarkedspriser på fisk og rejer. En tredje vigtig indtægtskilde er indtægterne fra partnerskabs- og fiskeriaftalerne med EU, der udgør cirka 3\% af den grønlandske landskasse (Finanslov for Grønland 2018 og Landskassens regnskab 2017). Ligesom bloktilskuddet, er indtægterne fra EU uafhængige af udsving i den globale markedsøkonomi. Dette kan dog ændre sig med forventningen om nedgang i EU's budget som følge af Storbritanniens exit fra EU. Bloktilskuddet og EUbistanden til den grønlandske landskasse giver en god stabilitet i den grønlandske finanslov og budgetprocessen, men rummer samtidig den vanskelighed, at finansieringen af øgede offentlige udgifter kræver en mere end proportional stigning i indtægterne fra skatter og afgifter eller helt nye og store indtægtskilder. 
Grønlands traditionelle økonomi fra kolonitiden og fremefter

For at kunne forstå baggrunden for den særlige måde, det grønlandske erhvervsliv og landets økonomi i dag er sat sammen på, må man kende landets udvikling fra tiden som sidestillet med et dansk amt til nutidens selvstyre. Derfor følger her en kort gennemgang af en række væsentlige nedslagspunkter.

Grønland var oprindeligt et traditionelt fanger-, fisker- og samlersamfund, som bestod af nomadiske Inuit-folk, der flyttede fra sted til sted og fra vinterboplads til sommerboplads afhængig af, hvor føden var at finde. Den struktur blev gradvist ændret med koloniseringen af Grønland i 1721 ved den dansk-norske præst, Hans Egede. Grønlands økonomiske udvikling blev herefter styret af det monopol, som den danske stat indførte i form af Den Kongelige Grønlandske Handel (KGH). Samfundet var styret af regler fastsat af centraladministrationen i København og havde ingen demokratiske institutioner af betydning.

Med koloniseringen i det 19. århundrede blev Grønlands befolkning markant større. I det vestlige Grønland blev der i 1901 optalt 11.190 grønlændere. I 1938 var antallet steget med knap 6.000 personer til 16.970 grønlændere (Sørensen 1983, 39). Det medførte en udvikling fra fanger-/jæger- og samlersamfund til en (industrialiseret) fiskerination, og andelen af fiskere steg fra 11,1\% i 1911 til 20,1\% i 1945 (Sørensen 1983, 40). Grønlands formelle kolonistatus blev ophævet i 1953 med revisionen af Danmarks riges grundlov og Grønland fik status som amt i det danske kongerige. Det indebar, at lovgivning og erhvervsøkonomiske dispositioner i al væsentlighed blev styret fra Christiansborg i Danmark. Fra 1953 og frem påbegyndte den danske regering en ny grønlandspolitik med det formål at opbygge et moderne grønlandsk samfund, der ville give mulighed for en fortsat udøvelse af det traditionelle fangsterhverv kombineret med en industrialisering og effektivisering af fiskeriet. Denne grønlandspolitik - som stod på i perioden fra 1953 og frem til hjemmestyrets indførsel - blev populært kaldet "G-50" og blev senere erstattet og suppleret af Grønlands-politikken af 1960, populært kaldet "G-60". Både G50 og G-60 indebar store og centralt styrede investeringer i infrastruktur i byer i Grønland, udført af dansk arbejdskraft og med en klar satsning på fiskerierhvervet som den industrialiseredes økonomis motor, kombineret med stærke statsligt styrede serviceerhverv inden for transport, kommunikationsteknologi, energi, boliger, levnedsmidler og uddannelse. Centraliseringen medførte tvungne fraflytninger og nedlæggelser af flere bygder. De store investeringer og udgifterne til et moderne velfærdssamfund blev båret af Danmark, men tanken var, at de grønlandske erhverv skulle klare den private indkomstdannelse. Mens infrastruktur, undervisning og sundhedsvæsen hurtigt udbyggedes med store forbedringer til følge, fulgte hverken diversificeringen eller privatiseringen af erhvervsstrukturen imidlertid med. Myndighederne begyndte derfor fra slutningen af 1950 'erne at bygge fiskefabrikker og indkøbe trawlere til det fiskeri, der skulle være det økonomiske grundlag. 


\section{Erhvervsstrukturen under Hjemmestyret (1979-2009)}

Hjemmestyreloven trådte i kraft den 1. maj 1979 og gav mulighed for at overtage en række kompetence- og ansvarsområder fra den danske stat. Pengeoverførelserne fra Danmark blev fra 1980 omlagt til bloktilskud - svarende til de udgifter, Danmark hidtil havde haft. Efterhånden som flere og flere områder blev overtaget af hjemmestyret, voksede bloktilskuddet, mens de direkte statsudgifter blev mindre. Samlet steg overførslerne fra 2 mia. kr. i 1980 til 3.4 mia. kr. i 2009 (Grønlands Selvstyres Finanslov 2018).

Økonomien under hjemmestyret var præget af virksomheder, der var drevet eller ejet af hjemmestyret, og fiskeriet var fortsat den helt dominerende sektor. På trods af de mange offentlige investeringer i en moderne fiskeflåde var det ikke lykkedes at skabe et kommercielt, selvfinansieret erhverv (Danielsen et.al. 1998, 39). Som eksempel fordelte arbejdsstyrken sig i 1990'erne med en fjerdedel på fiskeri og forarbejdning, en tredjedel på offentlig infrastruktur og en tredjedel på offentlig og privat administration. Anden beskæftigelse udgjorde en tiendedel. Offentligt ansatte i administration og de offentlig ejede virksomheder udgjorde dermed $60 \%$ af de beskæftigede.

Selvstyreloven af 21. juni 2009

Den 21. juni 2009 blev hjemmestyreloven erstattet af selvstyreloven. Blandt forskellene mellem Hjemmestyreloven og Selvstyreloven er blandt andet bestemmelser om, at grønlændere betragtes som et folk i sig selv (med ret til selvbestemmelse); at grønlandsk formelt set benævnes som det officielle sprog i Grønland, og at selvstyreloven giver flere muligheder for at overtage sagsområder, som hjemmestyreloven ikke gav adgang til. Selvstyreloven indeholder en bestemmelse om Grønlands adgang til selvstændighed, som indebærer, at "hvis det grønlandske folk træffer beslutning om selvstændighed, kan der indledes forhandlinger mellem regeringen og landsstyret om gennemførelse af selvstændighed for Grønland" (Selvstyreloven).

Den væsentligste forskel mellem hjemmestyreloven og selvstyreloven, for så vidt angår erhvervsudvikling og økonomi, er bestemmelsen om Grønlands mulighed for at overtage råstofområdet. Dette blev også den første opgave, som Naalakkersuisut (den grønlandske regering) gav sig i kast med ved selvstyrets indførelse. Inatsisartuts (det grønlandske parlament) lov nr. 7 af 7 . december 2009 om mineralske råstoffer og aktiviteter af betydning herfor (herefter betegnet "råstofloven") trådte i kraft med effekt pr. 1 . januar 2010.

Der har været store forventninger til indtægter i Grønlands økonomi ved overtagelsen af råstofområdet, hvorfor de "økonomiske relationer mellem Grønlands Selvstyre og Staten” også er adresseret i Selvstyrelovens kapitel 3. Kapitlet opridser de betingelser, der gør sig gældende, såfremt Grønland skulle få så mange indtægter fra mineralske råstoffer, olie og gas, at man ville kunne modregne indtægterne fra bloktilskuddet. Skulle der tilfalde Grønlands Selvstyre 75 mio. kr. eller mere i indtægter fra råstofaktiviteter i 
Grønland, vil statens tilskud til selvstyret reduceres med et beløb, der svarer til halvdelen af de indtægter, som i det pågældende år ligger over 75 mio. kr. Det er også beskrevet, at skulle den danske stats tilskud til Grønlands Selvstyre blive reduceret til 0 kr., kan der indledes forhandlinger mellem Naalakkersuisut og den danske regering om de fremtidige økonomiske relationer mellem Grønlands Selvstyre og den danske stat. Selvstyrelovens kapitel 3 beskriver med andre ord en proces for Grønlands (økonomiske) uafhængighed.

\section{Grønlands økonomi og erhvervsstruktur anno 2019 og i fremtiden?}

Hvis man vil kaste et blik på den grønlandske økonomi og erhvervsstruktur, som den ser ud i dag - og som den måske vil komme til at se ud i en fremtid med selvstændighed kan tendenserne på arbejdsmarkedet, i finanspolitikken, i politikken omkring investeringer i Grønland samt på områderne fiskeri, råstoffer, infrastruktur, turisme, energi, uddannelse, innovation og entreprenørskab være med til at tegne et billede af situationen.

\section{Finanspolitikken, arbejdsmarkedet og investeringer i Grønland}

Den grønlandske økonomi er for tiden i vækst og den offentlige gæld er lav. Alligevel ser det på sigt ud som om, at finanspolitikken i Grønland vil blive udfordret. Den helt store udfordring er demografien, hvilket også gør sig gældende i resten af Europa. Der er i disse år en meget stor andel af befolkningen i den erhvervsaktive alder, som snart skal pensioneres. Den anden større udfordring er, at der ikke er sket en tilstrækkelig diversificering $i$ erhvervsstrukturen, og at indtægterne til landskassen stadig kommer fra de samme, relativt få, kilder. De offentlige udgifter til især pensioner og hospitalsvæsen vil stige i fremtiden, og det udgiftspres er der ikke på nuværende tidspunkt luft til i Grønlands økonomi.

Grønlands Statistik har lavet en befolkningsfremskrivning, der viser en forventet befolkningstilbagegang fra 56.500 i 2018 til 52-53.000 i 2040. Det betyder, at der forventes en mindre arbejdsstyrke med den konsekvens, at skattegrundlaget bliver mindre. Dermed bliver der færre midler til at dække de øgede udgifter, som selvstyret har i dag, og som forventes at stige blandt andet på ældre- og sundhedsområdet som en konsekvens af den stigende andel af ældre og pensionister udenfor arbejdsmarkedet (Greenland in Figures 2018).

Økonomisk Råd for Grønland har beregnet en såkaldt finansindikator, som viser, at der er behov for en meget stram finanspolitik for at skabe balance i de offentlige budgetter, hvis den offentlige gæld, som andel af BNP, ikke skal stige frem til 2040. Sammenslutningen af arbejdsgivere i Grønland, Grønlands Erhverv, har populært beskrevet udfordringerne i Grønlands økonomi som et "dødens gab" (Grønlands Erhverv, 2013). Kort sagt betyder det, at udgifterne til løsning af samfundets "bundne" opgaver (sygehusvæsen, skoler, uddannelse og sociale forhold) vil komme til at overstige indtægterne - 
med mindre der indføres skrappe reformer, som reducerer de offentlige udgifter. Vist som graf danner linjerne for denne udvikling noget, der ligner et åbent haj-gab - deraf betegnelsen.

På udgiftssiden må man hæfte sig ved, at det offentlige forbrug er meget højt i Grønland. Den danske nationalbank har estimeret, at det offentlige forbrug pr. indbygger er hele 50\% højere end i Danmark, men der er ikke indikationer på, at det offentlige serviceniveau i Grønland skulle være tilsvarende højere (Christensen 2018 II). Forholdet kan i høj grad tilskrives smådriftsulemper blandt andet fordi, at befolkningen i Grønland bor meget spredt, fordelt over tusindevis af kilometer langs kysten. I dag er der cirka 30 bygder med et befolkningstal under 100 indbyggere. Det er alt andet lige meget dyrere per indbygger, hvis mennesker i en bygd skal have et serviceniveau, som svarer til det øvrige Grønland. Det vurderes samtidig, at årsagen til det høje forbrug også er forbundet med manglende produktivitet.

Erhvervsstrukturen i Grønland er domineret af fiskeriet, og arbejdsstyrken er i overvejende grad ansat her og i det offentlige system. Grafen nedenfor viser det samlede antal ansatte pr. industri, som afspejler erhvervsstrukturen i Grønland.

\section{Ansatte pr. industri - 2015}

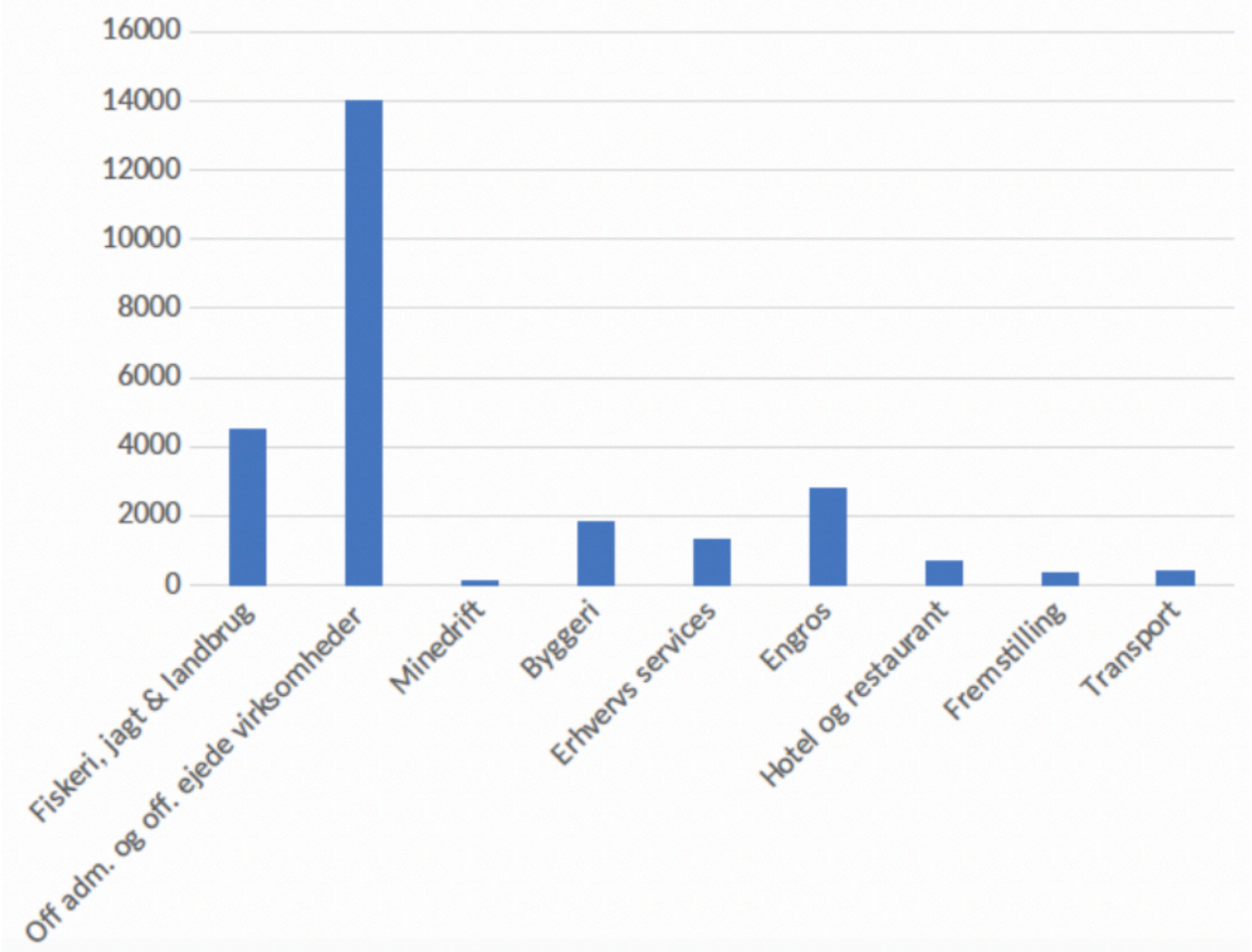

Figur 1: Arbejdsstyrken i Grønland - ansatte fordelt på erhverv/industri (Tal fra Grønlands Statistik 2015) 
Tallene viser, at over $40 \%$ er direkte ansat $\mathrm{i}$ den offentlige administration, men at mere end $60 \%$ af arbejdsstyrken har det offentlige som arbejdsgiver, hvis man tæller de offentligt ejede aktieselskaber med. Det er en fordeling, der belaster de offentlige finanser og understreger, at der ikke er sket et nybrud i diversificering (eller privatisering) i erhvervsstrukturen siden selvstyrets indførsel.

I researchen til nærværende artikel har forfatteren ledt efter en grønlandsk strategi for tiltrækning af udenlandske og direkte investeringer i Grønland med samlede overvejelser om, hvordan sådanne typer investeringer tiltrækkes til Grønland i en sådan grad, at de dels bidrager til at skabe en diversificering af erhvervslivet i Grønland og dels imødekommer behovet for private investeringer. En sådan strategi synes ikke at eksistere. Grønlands Selvstyre kunne med fordel få udarbejdet en koordineret og samlet strategi for tiltrækning af udenlandske og direkte investeringer i Grønland med henblik på at definere, hvordan en diversificering af Grønlands erhvervsliv kan se ud i fremtiden og potentielt dirigere Grønland på vej mod øgede private indtægter.

\section{Fiskeriet}

Fiskeriet er Grønlands største egentlige indtægtskilde og fundamentet for den private grønlandske økonomi. Cirka 95\% af vareeksporten stammer fra fiskeriet - heraf er næsten halvdelen rejer. Fiskeriet er imidlertid sårbart over for udsving i mængde og pris og blandt andet overfiskning har vist sig at være et problem. I 1972 blev de første fiskekvoter fastsat, og siden 1985 har hjemmestyret ved lov fastsat fangstkvoter. Grønlands Naturinstitut blev etableret i 1995 med henblik på at give Naalakkersuisut biologisk rådgivning på fiskeribestandene, hvori fangstkapaciteten er blevet reguleret. Men som i mange andre politiske og fordelingsmæssige hensyn, spiller bosætningsmønstret i Grønland også en rolle i fiskeripolitikken, som i nogle tilfælde er blevet indrettet ud fra beskæftigelseshensyn og bosætningsmønster, snarere end efter hensynet til bestanden. Grønlands økonomi har været i fremgang siden 90'erne, hvilket kan tilskrives fiskeriet (der flere gange har overskredet de mængder, som den biologiske rådgivning har anbefalet). De globale priser på fisk har siden 1990'erne været stigende, hvilket har været positivt for Grønlands økonomi. Det grønlandske fiskeri befinder sig i dag i en "krydskonjunktur", hvor fangsterne er faldende, mens priserne er stigende.

Med baggrund i ovenstående synes indførelsen af selvstyret ikke at have haft nogen stor indvirkning på udviklingen af fiskeriet eller diversificering af erhvervsstrukturen. Da erhvervsmulighederne i Grønland er få, og der er stor afhængighed af havets ressourcer, er det oplagt at give opmærksomhed til andre erhvervsmuligheder, der knytter sig til havet. En mulighed for at diversificere og nytænke Grønlands erhvervsstruktur er at se på mulighederne indenfor en "blå bioøkonomi for Grønland", som anbefalet af blandt andet Nordisk Ministerråd. 
Bioøkonomi er betegnelsen for de dele af økonomien, der baserer sig på biologiske og fornybare ressourcer fra land og vand for at producere traditionelle fødevarer, men også for at producere "utraditionelle" produkter i form af kemikalier, energi eller farmaceutiske produkter såsom kosmetik og helseprodukter. Det er for eksempel vurderet, at tang - som findes i rigelige mængder i Grønland - på lang sigt kan have en værdi op til cirka 100 mia. kr. på globalt plan i kraft af den øgede globale efterspørgsel (Nordic Council of Ministers, 2018). Omlægningen til en blå bioøkonomi kommer dog ikke af sig selv, idet det kræver en særlig samfundskoordineret tilgang, hvor det private erhvervsliv og private næringsdrivende samt de offentlige aktører (især forsknings- og videns-institutionerne, men også lovgivere og regering) går sammen om at udvikle et "laboratorium" for denne type udvikling, og på sigt skaber produkter, der kan skabe vækst i Grønland. Man kunne forestille sig, at en vej mod en nytænkning og videreudvikling af Grønlands velfungerende fiskeri kunne være at tænke i bio-økonomi som supplement til fiskeriet og som diversificering af erhvervsstrukturen i Grønland. En del af sådan et arbejde kunne indeholde et fokus på, hvordan grønlandske råvarer kan anvendes til nye produkter med henblik på forarbejdning samt salg og eksport til eksempelvis fødevareindustrien.

\section{Råstofindustrien}

På baggrund af Råstofloven fra 2010 udarbejdede Naalakkersuisut en råstofstrategi for perioden 2014-2018. I strategien stod der, at "der i perioden fra 2014 til 2018 vil skulle åbnes 3-5 miner, og ... at der hvert andet år vil vare 1-2 offshorebore-projekter. Strategiens tiltag skal enten bidrage til at sikre dette aktivitetsniveau eller tager udgangspunkt $i$, at niveauet realiseres inden udgangen af 2018." (Grønlands olie og mineralstrategi 2014-2018).

Ved midten af 2019 er der ikke åbnet 3-5 miner, og der har ikke været 1-2 offshoreboringer efter olie eller gas hvert andet år. Der er blevet foretaget én olieprøveboring af det australske olieselskab, Cairn Energy, i 2010-2012. Investeringerne i mineralefterforskning i Grønland toppede i 2011 med 705 mio. kr. og investeringerne er faldet støt til 130 mio. kr. i 2016 (Naalakkersuisut 2018). Udviklingen vendte dog til det mere positive i 2017, hvor de foreløbige tal viser efterforskningsinvesteringer på 193 mio. kr. Mulighederne på råstofområdet er i høj grad betinget af verdensmarkedspriserne. Disse har været nedadgående i en årrække siden indførelsen af selvstyret i 2009, og manglende investeringer i og indtægter fra råstoffer i Grønland kan derfor til dels tilskrives disse forhold.

\section{Muligheder på råstofområdet}

Efter en række magre år uden råstofudvinding synes der at være lys forude. I maj 2017 åbnede et projekt om udvinding af rubiner kaldet "Greenland Ruby". Minen ligger i Qe- 
qertarsuatsiaat (Fiskenæsset) cirka $130 \mathrm{~km}$. fra Nuuk og beskæftiger omkring 30 personer. I november 2018 blev et andet mineprojekt - med nogenlunde samme beskæftigelsesgrad - åbnet af det canadiske selskab Hudson Resources, der vil udvinde anorthosit,

Naalakkersuisut vurderer, at en række andre råstofprojekter nærmer sig udvindingsstadiet. Det gælder eksempelvis et jernmalmsprojekt i nærheden af Nuuk, et guldmineprojekt i Sydgrønland, et titaniumprojekt i Nordgrønland, et sjældne jordarts- og zirconiumprojekt samt et sjældne jordarts-og uranprojekt i Sydgrønland. Nogle af de nævnte projekter kan - ifølge oplysninger fra Naalakkersuisut - forventes at få udnyttelseslicenser i den nærmeste fremtid, men det afhænger i høj grad af, om selvstyret har de fornødne informationer og ressourcer til at give udnyttelseslicenser; om selskaberne kan rejse kapital, og hvordan markedspriserne på de enkelte råstoffer er og tegner til at blive i fremtiden. Såfremt et eller flere af projekterne realiseres, vil det potentielt kunne udgøre et bidrag til en mere diversificeret erhvervsstruktur i Grønland. Indtægterne fra disse projekter vil dog formentlig ikke være tilstrækkelige til at skabe et økonomisk grundlag, som kan erstatte bloktilskuddet på kort sigt.

Råstofområdet er et erhverv med en volatil prisstruktur og markedspriserne fluktuerer meget og hurtigt. Det er samtidig et ganske omkostningstungt erhverv, hvor både efterforskning og udvinding kræver store investeringer i udstyr og infrastruktur, og hvor det kan tage tid at opbygge profit. Skalaen for mineralsk råstofudvinding er fortsat meget lille i Grønland. Der vil være behov for langt mere aktivitet og langt flere aktive miner end både det nuværende og planlagte niveau, hvis råstofudvinding skal blive et bærende erhverv i fremtiden.

\section{Investering i infrastruktur}

Ved indførelsen af Selvstyret nedsatte Naalakkersuisut en række kommissioner til at belyse behovet for fremtidig udvikling af Grønland set i lyset af det generelle politiske ønske om selvstændighed. I den sammenhæng blev Transportkommissionen nedsat, og den afleverede sin betænkning i januar 2011. Betænkningen er et grundigt værk, der belyser økonomiske og samfundsmæssige konsekvenser, fordele og ulemper samt opstiller en række scenarier for så vidt angår trafik- og transportstrukturen i og for Grønland. Der kan ikke udledes én overordnet konklusion, men der er ikke tvivl om, at der er gensidig afhængighed mellem erhvervsudviklingen og den trafikale infrastruktur. I direkte forlængelse af behovet for at udvide og diversificere den grønlandske erhvervsstruktur er det tydeligt, at én af grundstenene hertil er en mere "optimal landingsbanestruktur" - kort sagt længere landingsbaner.

For at imødekomme behovene for at erstatte de eksisterende såkaldte Atlantlufthavne i Kangerlussuaq og Narsarsuaq, der blev bygget af det amerikanske luftvåben under 2. verdenskrig, har Selvstyret besluttet at udbygge og udvide de eksisterende landingsbaner i Nuuk fra 950 meter til 2.220 meter og i Ilulissat fra 845 meter til 2.200 meter. 
Til at forestå dette arbejde etablerede Naalakkersuisut i 2016 et aktieselskab, Kalaallit Airports, med det formål at anlægge, eje og drive lufthavne i Nuuk, Ilulissat og Qaqortoq.

Ét af de centrale udeståender er spørgsmålet om finansiering af udvidelsen af landingsbanerne. I august 2018 underskrev Naalakkersuisut en aftale med den danske stat om dansk økonomisk engagement i lufthavnsprojektet i Grønland og styrket erhvervssamarbejde mellem Danmark og Grønland (Statsministeriet \& Naalakkersuisut, 2018). Aftalen muliggør et dansk statsligt indskud på 700 mio. kr. i de budgetterede omkostninger på ca. 3,6 mia. kr. (Selvstyrets finanslov 2018), en statslig garanti på en låneramme på 450 mio. kr. i Nordisk Investeringsbank samt et genudlån på 450 mio. kr. til Kalaallit Airport. I aftalen fastslås det også, at den danske stat stiller et kapitalindskud på 20 mio. $\mathrm{kr}$. til rådighed samt bidrager til en erhvervspulje på 20 mio. kr.

Aftalen sendte en chokbølge ind i det politiske landskab i Grønland og skabte dønninger, der rakte langt ind i Naalakkersuisuts inderste cirkler og sprængte koalitionen mellem partierne Siumut, Atassut, Nunatta Qitornai og Partii Naleraq, idet Partii Naleraq gik ud af Naalakkersuisut. Partii Naleraqs formand, Hans Enoksen, forklarede det på følgende måde:

\section{"Staten [den danske] blander sig direkte i [grønlandsk] politik, og dermed stilles der store spørgsmål om grønlcendernes evne til at gøre noget selv. Det vil vi ikke vore med til, vores mål har varet grønlandsk selvstcendig- hed $i$ en årrcekke, og når der gøres sådan nu, så kan vi se, at vi bliver svoekket. Og det vil vi ikke voere med til" (Jyske Vestkysten 2018).}

Eksemplet viser, at målet om selvstændighed kan vurderes ud fra to vinkler: politisk selvstændighed og økonomisk selvstændighed - og at disse to vinkler ikke altid går hånd $\mathrm{i}$ hånd. En aftale mellem Naalakkersuisut og den danske stat, som må betragtes som en økonomisk håndsrækning og dermed en måde at opfylde ét delmål på vejen til økonomisk selvstændighed, kan stå som en modsætning til ønsket om politisk selvstændighed.

\section{Turisme}

Turisme anses som en af de sektorer, der kan give Grønland økonomisk vækst i fremtiden. En gennemgang af Naalakkersuisuts økonomiske redegørelse for 2018 og Grønlands turismestatistik (et samarbejde mellem Grønlands Statistik og Visit Greenland, Grønlands turismeorganisation) viser, at forøgelsen af turismen ikke er sket i det tempo, som det politiske niveau i Grønland har ønsket. Statistikken viser, at antallet af internationale gæster/rejsende til Grønland i 2017 på 62.484 personer, mens det i 2001 var på 65.720 personer, som er et fald på 3.236 personer (Grønlands Turismestatistik). Erfaringen fra markedsføringsindsatsen i perioden 2012-2015 har - trods en stigning i antallet af landbaserede turister i 2015 - endnu ikke indfriet succeskriterierne om et øget antal besøgende, øget omsætning og flere jobs i turismesektoren. Et lyspunkt har dog været afledte effekter 
i Grønland af den store vækst i turister til Island, som er estimeret til cirka 3 mio. turister om året, der enten besøger Island eller er i transit i Island.

I grafen nedenfor ses udviklingen i antallet af flypassagerer i Grønland og Island. Der er dels en markant forskel målt i absolutte tal, men også en vækst i Island, der ikke er på nær samme niveau i Grønland. Det skal dog nævnes, at væksten i Island er ekstraordinær og delvis skyldes bedre infrastruktur (landingsbaner) og en helt ekstraordinær prioritering af og vækst i turismen siden den finansielle krise omkring 2008. Men grafen kunne samtidig også indikere, at Grønland ikke har formået at indfri det potentiale, der ligger i turismen.

\section{Antal flypassagerer målt i tusinde}

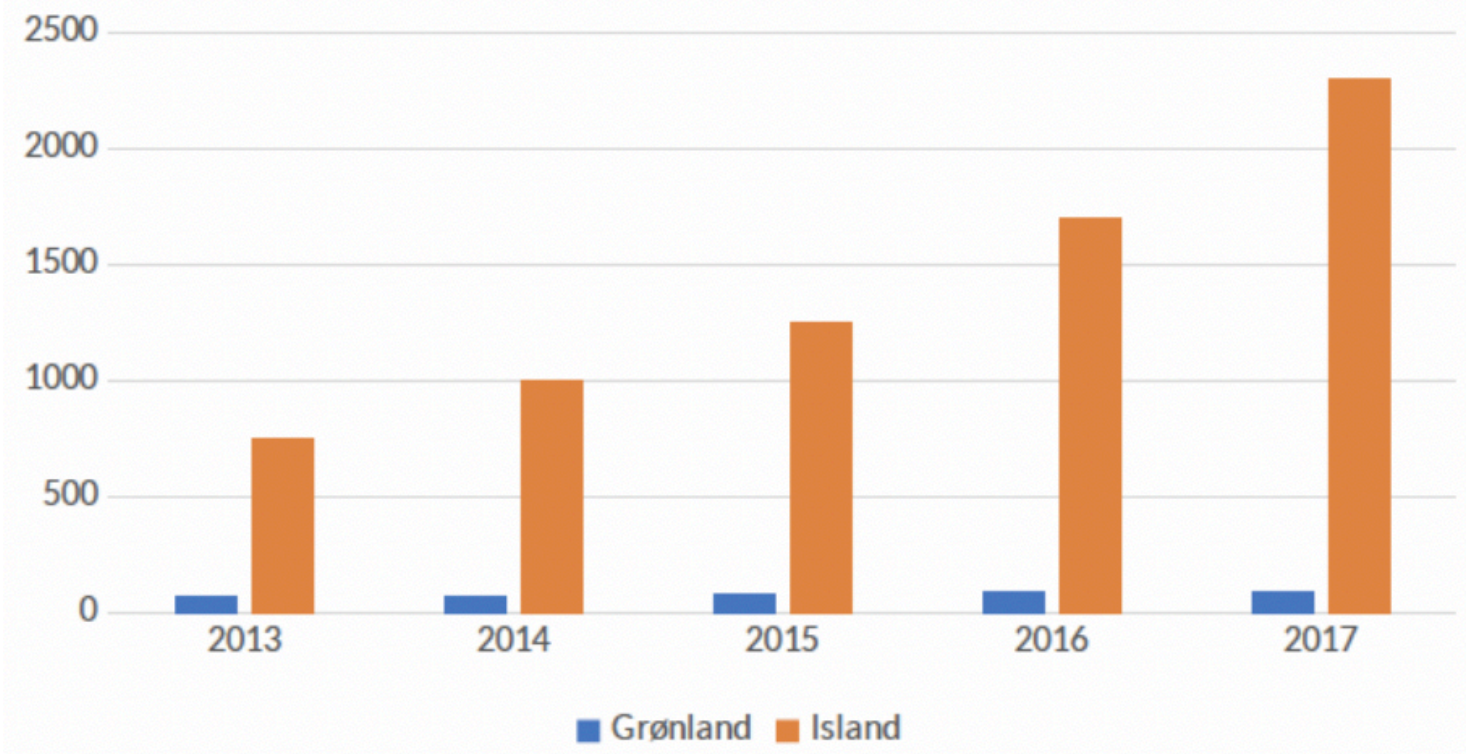

Figur 2: Antal flypassagerer til Grønland i perioden 2013-2017 (Grønlands Statistik)

Naalakkersuisut fik i 2014 udarbejdet en "analyse af afgiftsstrukturen for turismeerhvervet - barrierer og potentialer for udvikling af turisme i Grønland", der viser, at Grønland på en række parametre ikke er konkurrencedygtig sammenlignet med lignende turistmål som Island og Svalbard. Analysen viste, at Grønland opkræver høje afgifter på anløb af krydstogtskibe i forhold til de lande, der konkurreres med, og det samme gør sig gældende for afgifter i flytrafikken, blandt andet landings- og passagerafgifter. Landingsbanestrukturen er i den sammenhæng et kerneområde for at øge tilgængeligheden til Grønland. En anden analyse - foretaget af Rambøll - viser, at landingsbanestrukturen i Grønland er indrettet på en måde, der indebærer et omkostningsniveau, der er langt højere end sammenlignelige ruter andre steder i verden, hvilket blandt andet er med til at øge billetpriserne. Det påpeges, at forlængelse af landingsbaner i f.eks. Nuuk og Ilulissat ville kunne reducere omkostningerne med op til 30\% med tilsvarende mulighed for prisreduktion over tid. Der er således nogle strukturelle betingelser, der bestemmer prisniveauet i den grønlandske turismebranche - og det er et højt niveau. 
Der er taget et væsentligt skridt $\mathrm{i}$ forbedring af turismepotentialet med beslutningen om at udvide og/eller anlægge landingsbaner i Nuuk, Ilulissat og Qaqortoq, hvor mellemstore jetfly fra internationale destinationer kan lande. Erfaringer fra andre lande viser, at øget turisme skaber vækst i relaterede erhverv - eksempelvis i hotel- og restaurationsbranchen. Derfor er udviklingen af turisme helt afgørende for diversificeringen af økonomien i Grønland, og der er fortsat rum til forbedring på området. Naalakkersuisuts turismestrategi for perioden 2016-2020 har opstillet mål om at øge antallet af landbaserede turister fra de nuværende 37.000 til $74.500 \mathrm{i} 2040 \mathrm{og}$ at øge antallet af krydstogtpassagerer fra de godt 20.000 til ca. 39.000 i 2040. Altså en fordobling af antallet af både land- og vandbaseret turisme. De afledte samfundsøkonomiske effekter fra turismesektoren antages at kunne bidrage med at skabe 888 årsværk og 492 mio. kr. i omsætning om året i 2040. Når Selvstyret fylder 10 år i 2019, må dette stå sin prøve.

\section{Lavthængende frugter for turismeudviklingen i Grønland}

Aktørerne indenfor turismebranchen i Grønland afholdt i november 2018 en større konference, "Towards More Tourism", der havde til hensigt at tilvejebringe input til Naalakkersuisuts fremtidige turismestrategi. Blandt anbefalingerne var: At skabe stærke, sammenhængende turismestrategier på nationalt og regionalt niveau, der samlet set øger Grønlands konkurrenceevne som turismedestination; at etablere et nationalt netværk som kan sikre bedre og stærkere samarbejde på tværs af regionerne om at udvikle digitale services til turister; at sikre en smidigere adgang til nødvendig og kompetent arbejdskraft for turismeerhvervet gennem lovgivning samt at gøre bæredygtighed til en integreret del af kompetence- og erhvervsudviklingen, herunder i undervisning på folkeskoleniveau og under videreuddannelse.

Begreberne samarbejde, bæredygtighed og uddannelse samt kompetenceudvikling er nøgleord, hvis man skal skabe succes i grønlandsk turisme - og i grønlandsk økonomi generelt. Bæredygtigheds-strategien skal sikre, at Grønland ikke overbelastes af turister med natur- og miljømæssige skadevirkninger til følge, sådan som man har set det i Island og til en vis grad også Færøerne. Uddannelse og kompetenceudvikling skal sikre en turisme, der føres primært af lokale beboere med en autentisk historiefortælling for turisten til følge og med deraf følgende skatteindtægter for Grønland og potentielle nye initiativer; og samarbejde skal sikre, at der skabes sammenhæng i de initiativer, der tages på turismeområder. Det kan synes som naturlige fokusområder, der burde give sig selv, men det har vist sig ikke at være tilfældet.

\section{Uddannelse i Grønland}

En bredere erhvervsstruktur med øget beskæftigelse for lokalbefolkningen kræver et løft i uddannelsesniveauet. Der kan registreres fremgang i uddannelsesniveauet, men det går 
fortsat langsomt. Fundamentet for at hæve arbejdsstyrkens kvalifikationer i Grønland lægges i folkeskolen og nogle vil endda hævde, at det sker før folkeskolen. I dag anvender Grønland mange ressourcer på folkeskolen og mange hævder, at det ikke nødvendigvis er et spørgsmål om at tilføre flere midler til uddannelsessystemet, men snarere et spørgsmål om at sikre et godt udbytte af de ressourcer, der tilføres systemet.

På nogle punkter er det tydeligt, at et højt udgiftsniveau ikke følges af en tilsvarende kvalitet. To rapporter udarbejdet af Danmarks Evalueringsinstitut i henholdsvis 2015 og 2016 har peget på, at både folkeskolen og læreruddannelsen har meget store problemer med det faglige niveau. Rapporten fra foråret 2015 var en kritik af den grønlandske folkeskole, som kort sagt vurderes at fungere dårligt (Danmarks Evalueringsinstitut, 2015). I 2016 blev rapporten om folkeskolen fulgt op af en endnu mere kritisk evaluering af læreruddannelsen (Danmarks Evalueringsinstitut, 2016), som "har en roekke alvorlige kvalitetsudfordringer og ikke på en tilfredsstillende måde imødekommer behovet for kvalificerede loerere i folkeskolen". Det siger sig selv, at dette ikke er befordrende for udviklingen af Grønlands erhvervsliv og Grønlands nuværende og fremtidige økonomi.

Rapporterne om folkeskolen og læreruddannelsen peger på, at en stærkere politisk opbakning - herunder lokalpolitisk - og støtte fra forældrene, vil kunne fremskynde de nødvendige ændringer. Ser man på den samlede andel af befolkningen med en uddannelse, er der sket en forbedring siden selvstyrets indførelse.

\section{Uddannelse, antal studerende der afslutter udd.}

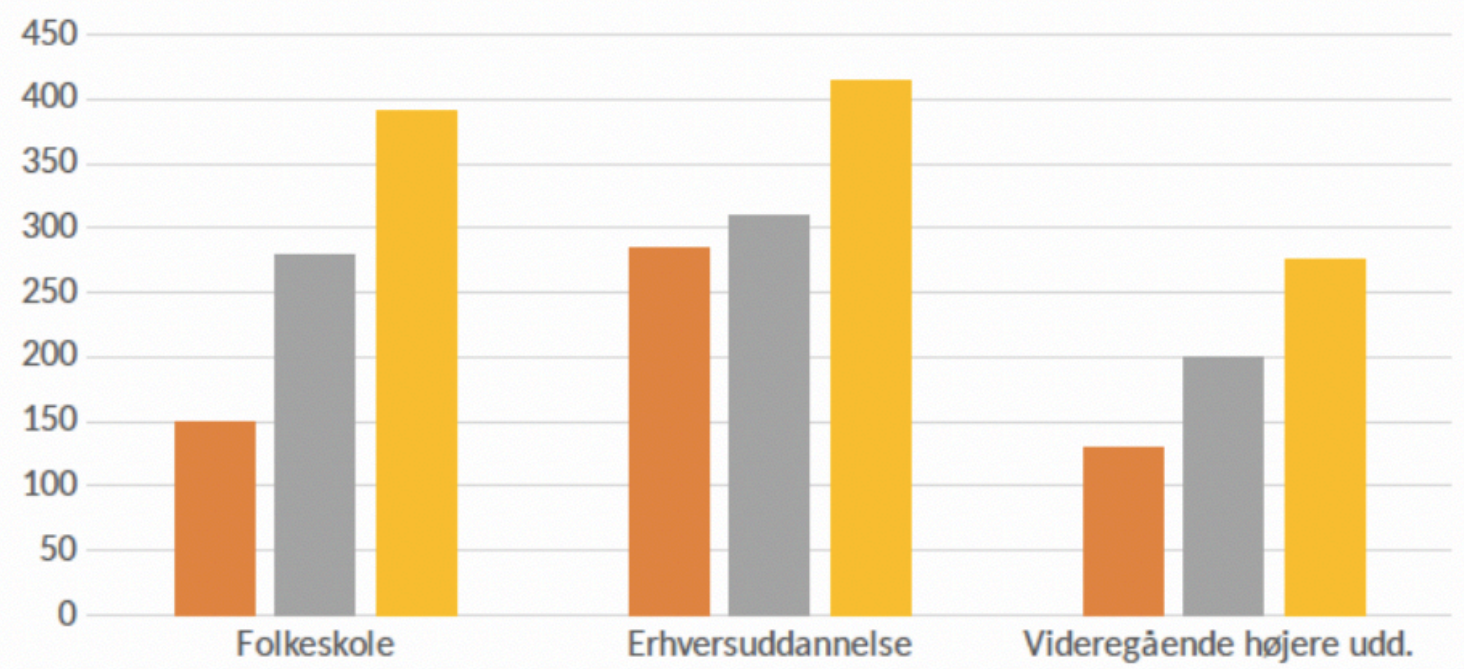

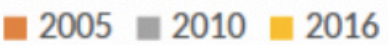

Figur 3: Antal personer, der færdiggør en uddannelse i perioden 2005-2010 (Grønlands Statistik) 
I grafen ovenfor ses det, at antallet af personer, der færdiggør en folkeskoleeksamen og en erhvervsuddannelse, er steget. Grafen viser til gengæld også, at antallet, der har færdiggjort en længerevarende uddannelse, ikke er steget i samme takt. Omkring halvdelen af alle 25-64-årige i Grønland har ingen uddannelse ud over gymnasiet. Til sammenligning gælder det for cirka en fjerdedel af de unge i de andre nordiske lande (Greenland in Figures, 2018).

Uddannelserne kan i dag ikke følge med efterspørgslen på uddannede personer. Der er taget initiativer vedrørende læreruddannelsen, men det vil tage tid, før de slår igennem på det generelle faglige niveau i folkeskolen. Der skal formentlig flere parallelle initiativer til for at ændre afgørende på udviklingen.

Energi

I Grønland - med det spredte bosætningsmønster fordelt på byer og bygder langs kysterne - er der tradition for brug af fossile brændstoffer og især i bosteder, der kræver brug af dieselgeneratorer. Det kan være for at sikre sig en mere stabil energiforsyning eller som bistand i nødsituationer. Grønlands Statistik viser, at der importeres fossile brændstoffer for cirka 700 mio. kr. om året. Samtidig viser tallene fra 2012-2016 også, at forbruget af fossile brændstoffer ligger på ca. $80-85 \%$ af det totale forbrug, mens vedvarende energi (primært vandkraft) udgør ca. 15-20\% af det totale forbrug, hvilket ses af grafen nedenfor.

\section{Energiforbrug}

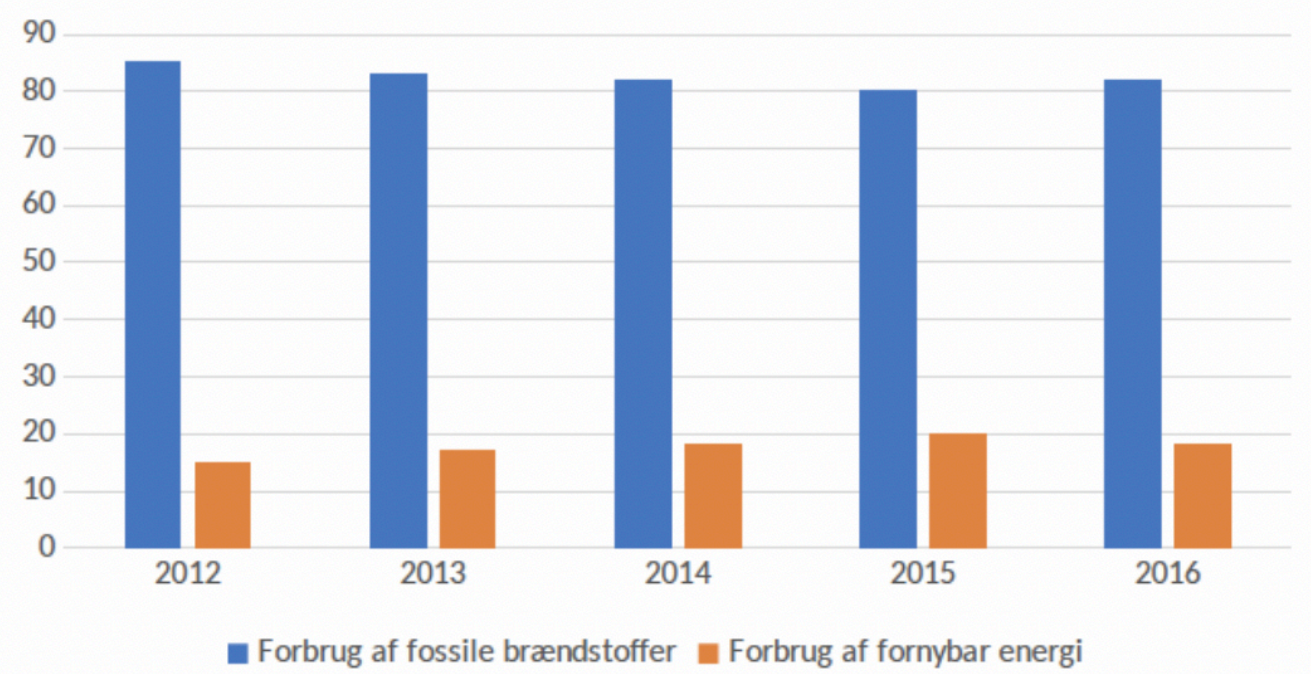

Figur 4: Energiforbruget i Grønland fordelt på fossile brændstoffer og fornybar energi (Grønlands Statistik)

Vandkraft er i dag den vigtigste vedvarende energikilde i Grønland, hvilket er en positiv, bæredygtig udvikling. De fem vandkraftværker, der er opført siden 1993, forsyner i alt seks byer og udgør dermed en vigtig del af energiforsyningen. Værkerne spiller også en positiv rolle i forhold til samfundsøkonomien, forsyningssikkerheden og naturligvis miljøet. 
I lyset af de årlige 700 mio. kr., som Grønland bruger på fossile brændstoffer, vil det være interessant at vurdere, hvad en yderligere transformation til mere bæredygtige og vedvarende energikilder vil kunne medføre af lokale arbejdspladser og lokale investeringer. Naalakkersuisut peger selv på, at lagring af overskudsenergi fra eksempelvis vandkraftværkerne eventuelt ville kunne bidrage til en forretning omkring etablering af datacentre i Grønland til serverparker mv. Naalakkersuisut skriver i sin sektorplan for energiområdet, at man ønsker at se på dette forretningsområde, men også i den sammenhæng synes der at mangle nogle sammenhængende overvejelser, som med fordel kan adresseres i en koordineret og samlet strategi for tiltrækning af udenlandske og direkte investeringer i Grønland.

\section{Entreprenørskab og innovation}

En måde at styrke erhvervsudviklingen på er ved at fremme entreprenørskab og innovation. Hvis man ser på antallet af investeringer, som det grønlandske investeringsselskab Greenland Venture foretager, ser den grønlandske iværksætterånd ikke ud til at stortrives. I grafen nedenfor kan man se, at investering i nye projekter ligger på et ret begrænset niveau; mellem 1 og 2 virksomheder om året.

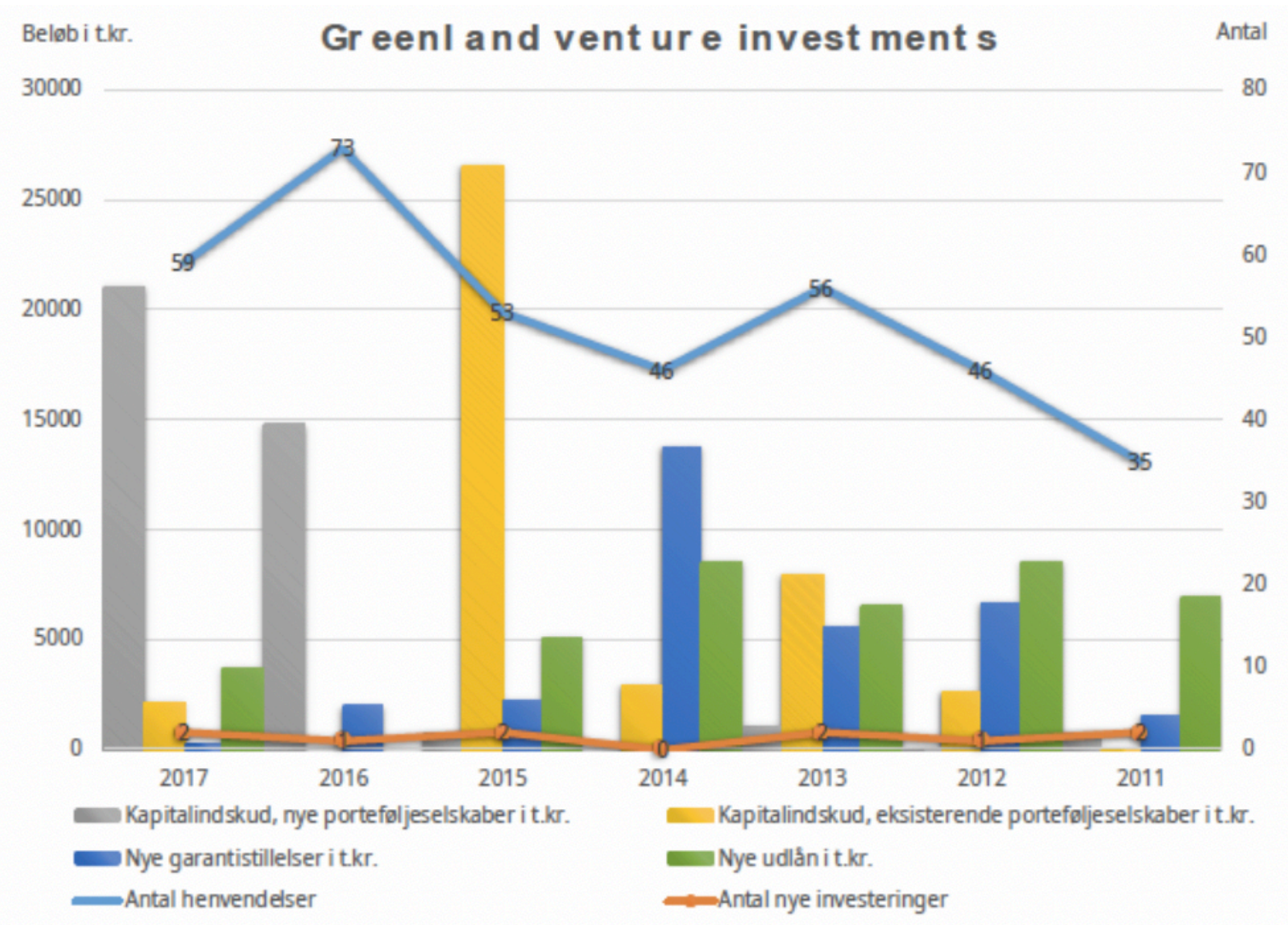

Figur 5: Greenland Ventures investeringer i perioden 2010-2016 (Kilde: www.venture.gl). 
En rapport udarbejdet af Fonden for Entreprenørskab på opdrag af Nordisk Ministerråd (Nordic Council of Ministers 2018 a) viser, at iværksætteri i det store og hele mangler på skoleskemaet og at der hidtil ikke har eksisteret en fælles strategi og satsning på området, som både uddannelser, erhvervsliv og offentlige myndigheder har støttet. Den manglende uddannelse indenfor iværksætteri betyder også, at kun ganske få virksomheder startes af studerende. Omvendt viser rapporten, at der er et stort potentiale for at integrere entreprenørskab i undervisningen med relativt få midler. Fonden for Entreprenørskab har etableret en tilstedeværelse i Grønland i 2018 med henblik på at opmuntre til iværksætterånd i undervisningen i folkeskolen og "Mind Your Own Business" har etableret kontor i Grønland i 2019 med henblik på at introducere drenge i alderen 13 til 21 år til at etablere mikrovirksomhed (myob.dk).

Der er således taget initiativer for at skabe opmærksomhed på innovation og iværksætteri, som kan bidrage til en diversificering af Grønlands økonomi på lidt længere sigt. Initiativerne er som udgangspunkt taget andre steder fra end selvstyret - eksempelvis i Nordisk Ministerråd eller fra private aktører, men over tid er nogle af de udefrakommende initiativer blevet inkorporeret i selvstyrets finanslov, hvilket er tilfældet med Fonden for Entreprenørskabs tilstedeværelse i Grønland.

Der kan med fordel tænkes mere i at oprette små og mellemstore virksomheder, hvor de kulturelle og kreative industrier og erhverv kommer i spil. Nordisk Ministerråd pegede i sin "Arctic Business Analysis" på, at eksempelvis filmindustrien kan udvikles i Nordens Arktis. Norges filmindustri er i vækst og tjente ca. 6 mio. $€$ (ca. 45 mio. kr.) i 2012. I 2014 opnåede filmindustrien i Island en produktionsværdi på mere end 100 mio.€ (ca. 750 mio. kr.) (Nordic Council of Ministers 2018 c). Der bør i den kontekst ses på, hvorvidt der kan laves incitamentsstrukturer fra Naalakkersuisuts side med henblik på at tiltrække filmindustrien til at lave film i Grønland og styrke den grønlandske filmindustri, som i dag tæller cirka 50 personer.

\section{Konklusion}

Det er fristende at spørge, om økonomien og erhvervsudviklingen i Grønland "ender i fisk"? Man kan være tilbøjelig til at svare "ja”. Kigger man på den nuværende økonomi og erhvervsstruktur er der ikke tvivl om, at fundamentet for nuværende ligger i fiskeriet og ikke særlig mange andre steder. De øvrige indtægtsgivende sektorer har ikke samme volumen eller vækst og økonomien kan derfor ikke hævdes at være diversificeret.

Artiklen viser, at fundamentet for Grønlands økonomi og erhvervsstruktur siden 1950-60'erne har været baseret på en moderne fiskeindustri og Grønland har i dag en moderne og effektiv fiskeflåde. Artiklen viser også, at erhvervsstrukturen i Grønland fortsat er énstrenget, og dermed sensitiv, og ikke i sig selv kan oppebære de indtægter, der pt. kommer fra henholdsvis det danske bloktilskud og tilskuddet fra EU, som beløber sig til cirka $60 \%$ af selvstyrets indtægter. 
Spørgsmålet er, hvad skal der til for at kunne skabe et grundlag for indtægter fra andre kilder? Artiklen peger på, at man i Grønland bør (i) udarbejde (og implementere) en samlet og koordineret strategi for tiltrækning af udenlandske og direkte investeringer til Grønland samt (ii) udarbejde (og implementere) en strategi for udvikling af havets ressourcer i en bio-økonomisk ramme.

Strategier kan dog ikke stå alene i udviklingen af Grønlands økonomi. Artiklen peger derfor også på, at en række erhvervsområder med fordel kan undersøges og understøttes. Grønland kan eksempelvis (i) nytænke forretningsmuligheder og produkter indenfor de marine erhverv - det kan være fiskeri af nye arter, produktudvikling indenfor eksisterende arter og/eller udvikling af den blå bio-økonomi såsom forarbejdning af fiskemel af fiskeaffald og brug af andre hidtil uudnyttede ressourcer såsom tang. Satsningen på (ii) uddannelse og undervisning indenfor innovation og entreprenørskab skal fortsætte samtidig med at (iii) en udvikling og kommercialisering af kulturelle og kreative industrier understøttes, og (iv) der fortsat arbejdes dedikeret på at udvikle tiltag indenfor turismeindustrien.

Som forudsætninger for en diversificering af den grønlandske erhvervsstruktur og for at skabe vækst i den grønlandske økonomi er det nødvendigt med følgende tre indsatser: 1) at styrke uddannelsesniveauet i Grønland i form af en fortsat stigning i antallet af færdiguddannede til det grønlandske arbejdsmarked; 2) at foretage en koordineret og strategisk tilgang for tiltrækning (og fastholdelse) af arbejdskraft og 3 ) at lave samfundsmæssige reformer, der imødekommer de demografiske udfordringer. Meget af dette er i gang, men ærmerne skal fortsat smøges op, hvis ikke det hele skal ende i fisk. 
Litteratur

Amtsavisen (2018). Lufthavnsstrid og partiexit kan kaste Grønland ud i nyvalg. Tilgængelig på: https://amtsavisen.dk/indland/Lufthavnsstrid-og-partiexit-kan-kasteGroenlandud-i-nyvalg/artikel/403887 [Tilgået d. 01.12.2018]

Aningaasaqarnermut Siunnersoqatigiit/Økonomisk Råd (2018). Nunatta Aningaasaqarnera/Grønlands økonomi 2018. Nuuk, Grønland. Tilgængelig på: https://naalakkersuisut.gl/ /media/Nanoq/Files/Attached\%20Files/Finans/DK/Oekonomisk\%20raad/2018\%20-\%20\%C3\%B8konomisk\%20r\%C3\%A5ds\%20rapport\%20dk.pdf [Tilgået d. 19.05.2019]

Aningaasaqarnermut Siunnersoqatigiit/Økonomisk Råd (2017). Nunatta Aningaasaqarnera/Grønlands økonomi. Nuuk, Grønland.

Aningaasaqarnermut Siunnersoqatigiit/Økonomisk Råd (2016). Nunatta Aningaasaqarnera/Grønlands økonomi. Nuuk, Grønland.

Bianco, N. (2018). Kan man leve af tang? Sermitsiaq, nr. 6. Tilgængelig på: www.sermitsiaq.ag

Christensen, A.M. (2016). Aktuelle tendenser i Grønlands økonomi. Danmarks Nationalbank kvartalsoversigt. 2. kvartal, 2016. Tilgængelig på: https://www.nationalbanken.dk/da/publikationer/Documents/2016/06/Aktuelle_tendenser_i_den_groenlandske_oekonomi_KVO2_16.pdf [Tilgået d. 01.12.2018]

Christensen, A.M. (2018 I). Stcerk voekst og mangler på arbejdskraft. Danmarks Nationalbank. Tilgængelig på: http://www.nationalbanken.dk/da/publikationer/Documents/2018/11/ANALYSE_Nr.\%2020_Gr\%C3\%B8nlandsk\%20\%C3\%B8konomi_DK.PDF\#search=Gr\%C3\%B8nland [Tilgået d. 01.12.2018]

Christensen, A.M. (2018 II). Grønland udfordret trods stcerk økonomi. Danmarks Nationalbank. Tilgængelig på: http://www.nationalbanken.dk/da/publikationer/Documents/2017/08/Analyse_Gr\%C3\%B8nland\%20udfor-

dret $\% 20$ trods $\% 20$ st $\%$ C3\%A6rkt $\% 20$ fiskeri.pdf\#search=Gr\%C3\%B8nland. [Tilgået d. 01.12.2018]

Danielsen, M.; Andersen, T.; Knudsen, T. \& Nielsen, O. (1998): Mål og strategier i den grønlandske erhvervsudvikling. Nuuk: Grønlands Statistik.

Danmarks Evalueringsinstitut (2015). Grønlands folkeskole. Tilgængelig på https://www.eva.dk/grundskole/groenlands-folkeskole [Tilgået d. 01.12.2018]

Danmarks Evalueringsinstitut (2016). Loereruddannelsen. Evaluering af Grønlands loereruddannelse på Ilinniarfissuaq. Tilgængelig på: https://www.eva.dk/videregaaende-uddannelse/laereruddannelsen-evaluering-groenlands-laereruddannelsepaa [Tilgået d. 01.12.2018]

Folketinget (2018). Redegørelse 3/10 18 om samarbejdet $i$ Arktis. Tilgængelig på: https:/www.ft.dk/ripdf/samling/20181/redegoerelse/R2/20181_R2.pdf

Fraser Institute (2018). Annual Survey of Mining Companies 2017. Tilgængelig på: https://www.fraserinstitute.org/studies/annual-survey-of-mining-companies2017 [Tilgået d. 01.03.2019] 
Greenland Minerals Authority (s.d.). Tilgænglig på: https://www.govmin.gl/en/geo$\operatorname{logy} /$ events/news/

Grønlands Erhverv (2013). Fremtidsscenarier for Grønland. Tilgængelig på: http:/ge.ga.gl/Portals/0/Erhvervsudvikling/Rapporter/Gr\%F8nland\%20Omskrevet\%20DK.pdf. [Tilgået d. 01.12.2018]

Grønlands turismestatistik (s.d). Tilgængelig på: http://www.tourismstat.gl

Gyldendals Encyklopædi - den store danske (s.d). Tilgængelig på: www.denstoredanske.dk

Inatsisartut (2010). Inatsisartutlov nr. 7 af 7. december 2009 om mineralske råstoffer og aktiviteter af betydning herfor (råstofloven). Tilgængelig på: http://lovgivning.gl/Lov?rid=\%7B4F8B6CD0-3E04-4476-A332-2A814FBA35A1\%7D. [Tilgået d. 01.12.2018]

Inatsisartut (2017). Landskassens regnskab 2017. Tilgængelig på: https://ina.gl/dvd/ EM2018/pdf/media/2535199/pkt11_em2018_landskassensregnskab2017_da.pdf. [Tilgået d. 01.12.2018]

Jydske Vestkysten (9. september 2018). Partii Naleraq forlader Grønlands regering efter lufthavnsstrid. Tilgængelig på: https://www.jv.dk/indland/Partii-Naleraq-forlader-Groenlandsregering-efter-lufthavnsstrid/artikel/2642377. [Tilgået d. 01.12.20 18]

Kalaallit Airport. Tilgængelig på: http://kair.gl/da/ [Tilgået d. 01.12.2018]

Kalaallit Nunatta Radio (KNR 9. september 2018). Partii Naleraq har forladt koalitionen. Tilgængelig på: https://www.jv.dk/indland/Partii-Naleraq-forlader-Groenlandsregeringefter-lufthavnsstrid/artikel/2642377. [Tilgået d. 01.12.2018]

Kalaallit Nunatta Radio (KNR): Naalakkersuisut - vandkraft skal tiltrække investorer. Tilgængelig på: https://knr.gl/da/nyheder/vandkraft-skal-tr\%C3\%A6kke-investorer-til-gr\%C3\%B8nland. [Tilgået d. 01.12.2018]

Marfeldt, B. (2014). Minister: Grønlands oliefond udgør 435 milliarder kr. i 2060. Tidsskriftet Ingeniøren. Tilgængelig på: https://ing.dk/artikel/minister-groenlandsoliefond-udgoer-435-milliarder-kr-i-2060-166383. [Tilgået d. 01.12.2018]

Naalakkersuisut/Grønlands Statistik (2018). Greenland in Figures 2018. Tilgængelig på: http://www.stat.gl/publ/da/GF/2018/pdf/Greenland\%20in\%20Figures\%202018 .pdf. [Tilgået d. 01.12.2018]

Naalakkersuisut (2014). Grønlands olie- og mineralstrategi 2014-2018. Tilgængelig på: https://naalakkersuisut.gl/ /media/Nanoq/Files/Publications/Raastof/DK/Gr\%C3 \%B8nlands\%20olie\%20og\%20mineralstrategi\%202014\%202018.pdf. [Tilgået d. $01.12 .2018]$

Naalakkersuisut (2018). Finanslov for Grønland 2018. Tilgængelig på: https://naalakkersuisut.gl/ /media/Nanoq/Files/Attached\%20Files/Finans/DK/Finanslov/ 2018 /FFL2018\%20\%20incl\%20sidetal\%20og\%20linket\%20indholdsfortegnelse \%20\%20DK\%20til\%20tryk.pdf. [Tilgået d. 01.12.2018]

Naalakkersuisut (2014). Analyse af afgiftsstrukturen for turismeerhvervet - Barrierer og 
potentialer for udvikling af turisme i Grønland. Tilgængelig på: https://naalakkersuisut.gl/ /media/Nanoq/Files/Publications/Erhverv/DA/Analyse\%20af\%20b arrierer\%20for\%20udvikling\%20af\%20turistpotentialet $\% 20 \mathrm{i} \% 20 \mathrm{Gr} \% \mathrm{C} 3 \% \mathrm{~B} 8 \mathrm{nl}$ and\%20-\%20version\%203\%201\%202014\%20DOK1437275.pdf [Tilgået d. $01.12 .2018]$

Naalakkersuisut (2016). Turismeudvikling i Grønland. Hvad skal der til? National sektorplan for turisme 2016-2020. Tilgængelig på: https://naalakkersuisut.gl/ /media/Nanoq/Files/Hearings/2015/Turismestrategi/Documents/Turismestrategi\% 202016-2020\%20FINAL\%20DK.pdf [Tilgået d. 01.12.2018]

Naalakkersuisut (2017). Sektorplan for energiforsyning. Tilgængelig på: https://naalakkersuisut.gl/ /media/Nanoq/Files/Hearings/2017/Hoering\%20af\%20udkast\%20 til\%20sektorplan\%20for\%20energi\%20og\%20vandforsyning/Documents/Sektorplan\%20version\%2027102017.pdf. [Tilgået d. 01.12.2018]

Naalakkersuisut (2017). Billig energi, grøn energi og rent drikkevand til alle. Naalakkersuisut ruller omfattende og langsigtet energireform ud - første skridt er prisnedsættelse på el og vand. Tilgængelig på: http://www.nukissiorfiit.gl/wp-content/uploads/2018/07/Pjece-om-energireform-DK-1.pdf. [Tilgået d. 01.12.2018]

Naalakkersuisut (2018). Økonomisk redegørelse 2018. Tilgængelig på: https://naalakkersuisut.gl/ /media/Nanoq/Files/Publications/Finanser/Okonomisk\%20Redegorelse\%202018\%20Dan\%20A4.pdf [Tilgået d. 01.12.2018]

Nordic Council of Ministers (2018 a). Creative and cultural industries. Tilgængelig på: http://norden.-diva-portal.org/smash/get/diva2:1175681/FULLTEXT01.pdf [Tilgået d. 01.12.2018]

Nordic Council of Ministers (2018 b). Arctic Business Analysis - Bioeconomy. Tilgængelig på: http://norden.diva-portal.org/smash/record.jsf?pid=diva2\%3A1175656\&dswid=-2861 [Tilgået d. 01.12.2018]. 10.6027/ANP2018-706

Nordic Council of Ministers (2018 c). Arctic Business Analysis - Entrepreneurship and Innovation. Tilgængelig på: http://norden.diva-portal.org/smash/get/diva2:1175 621/FULLTEXT01.pdf

Norden Business (s.d.). Tilgængelig på: https://nordenbusiness.org/dk/groenland/etablering. [Tilgået d. 01.12.2018]

Nukissiorfiit (det grønlandske energiforsyningsselskab). Tilgængelig på: http://www.nukissiorfiit.gl/

Politiken (2018). Lufthavnsstrid og partiexit kan kaste Grønland ud i nyvalg. Politiken. Tilgængelig på: https://politiken.dk/oekonomi/dkoekonomi/art6693769/Lufthavnsstrid-og-partiexit-kankaste-Gr\%C3\%B8nland-ud-i-nyvalg. [Tilgået d. 01.12.2018]

Rambøll Consulting (2015). Turisme. Udvikling og vækst gennem ændret lufthavnsstruktur. Tilgængelig på: https://naalakkersuisut.gl/ /media/Nanoq/Files/Publications/Erhverv/Turisme\%20udvikling\%20og\%20vaekst\%20gennem\%20aendret \%20lufthavnsstruktur/TURISME\%20-\%20UDVIKLING\%20OG\%20V\%C3\%8 
6KST\%20GENNEM\%20\%C3\%86NDRET\%20LUFTHAVNSSTRUKTUR $\% 2$

0DK.pdf. [Tilgået d. 01.12.2018]

Sermitsiaq medieavis (2019): Venturedirektør - fantastisk udvikling i iværksætteri. Tilgængelig på: https://sermitsiaq.ag/venture-direktoerfantastisk-udvikling-i-ivaerksaetteri. [Tilgået d. 01.03.2019]

Sermitsiaq medieavis (2016). Seminariet får dumpekarakter. Tilgængelig på: https://sermitsiaq.ag/node/186891. [Tilgået d. 01.12.2018]

Sermitsiaq medieavis (2018): Lufthavnspakken er vedtaget. Tilgængelig på: https://sermitsiaq.ag/lufthavnspakken-vedtaget. [Tilgået d. 01.12.2018]

Sermitsiaq medieavis (2018). Vittus: Disse mineprojekter tror vi på. Tilgængelig på: https://sermitsiaq.ag/node/208325. [Tilgået d. 01.12.2018]

Statsministeriet (2009). Lov om Grønlands selvstyre. Tilgængelig på: http://www.stm.dk/multimedia/selvstyreloven.pdf

Statsministeriet \& Naalakkersuisut (2018). Aftale mellem regeringen og Naalakkersuisut om dansk engagement i lufthavnsprojektet i Grønland og styrket erhvervssamarbejde mellem Danmark og Grønland. Tilgængelig på: http://www.stm.dk/multimedia/10-09-2018_Aftale_mellem_regeringen_og_Naalakkersuisut.pdf. [Tilgået d. 01.12.2018]

Sørensen, A.K. (1983). Danmark-Grønland i det 20. århundrede - en historisk oversigt. København: Nyt Nordisk Forlag Arnold Busck.

Têtu, P.-L. \& Lasserre, F. (2017). Chinese investment in Greenland's mining industry: Toward a new framework for foreign direct investment. The Extractive Industries and Society, årg. 4(3), s. 661-671.

Transportkommissionen (januar 2011). Transportkommissionen - betænkning. Tilgængelig på: https://naalakkersuisut.gl/ /media/Nanoq/Files/Publications/Departement $\% 20$ for $\% 20$ Sundhed $\% 200 g \% 20$ Infrastruktur/Infrastrukturkontoret/Bet\%C3\%A6nkningen\%20DK.pdf. [Tilgået d. 01.12.2018]

TV2 (2018). Grønlandsk parti trækker sig fra regering et døgn før Løkkebesøg. TV2. Tilgængelig på: http://nyheder.tv2.dk/politik/2018-09-09-gronlandsk-parti-traekkersig-fraregering-et-dogn-for-lokke-besog. [Tilgået d. 01.12.2018]

Vinther, H. (2017). De grønlandske råstoffer - mineeventyret, der blev væk. Tidsskriftet Ingeniøren. Tilgængelig på: https://ing.dk/artikel/de-groenlandske-raastoffer-mineeventyretblev-vaek-203806. [Tilgået d. 01.12.2018] 